\title{
PENGARUH PEMBERIAN ABU BOILER TERHADAP PERTUMBUHAN DAN HASIL BAWANG MERAH (Allium ascalonicum L.) DI LAHAN GAMBUT
}

\author{
Effect Flyash on Onion (Allium ascalonicum L.) Groth and Yield in Peatland
}

\author{
Yeni Hartati, Nelvia \\ Department of Agrotechnology, Faculty of Agriculture, University of Riau \\ Email: yenihartati71@yahoo.co.id (0822-8836-6860) \\ [Diterima: Desember 2016; Disetujui: Maret 2017]
}

\begin{abstract}
The aim of research to study the effect of Boiler ash origin palm oil mills (PKS) and the pulp on growth and yield of onion (Allium ascalonicum L.) on peatland. Research conducted at the experimental farm, Faculty of Agriculture, University of Riau, Rimbo Panjang village, Kampar District, Riau Province from August to November 2015. The study using the split-plot design (Split Plot Design), as the main plot, Boiler ash consists of two levels (plant origin MCC and pulp), and the subplot is boiler ash doses $(0,3,6$, and 9 tons/ha). Parameters measured were plant height, tuber number, the weight of tuber per hill, and tuber yield per $\mathrm{m} 2$. The results showed that plant height increased markedly in the application of 3 tons/ha ash from two sources, the number of tubers per clump sample increased markedly on the application of 6 tons/ha ash from PKS, as well as tuber weight per hill and tuber yield per $m 2$ tends to increase with the application 3-9 tonnes/ha, the increase is greater with higher doses of ash from both sources.
\end{abstract}

Keywords: Boiler ash, Peat, and Onion.

ABSTRAK

Tujuan penelitian untuk mempelajari pengaruh abu boiler yang berasal dari limbah pabrik kelapa sawit (PKS) dan pulp terhadap pertumbuhan dan hasil bawang merah (Allium ascalonicum L.) di lahan gambut. Penelitian dilakukan di kebun percobaan, Fakultas Pertanian, Universitas Riau, Desa Rimbo Panjang, Kabupaten Kampar, Provinsi Riau dari Agustus hingga November 2015. Penelitian menggunakan Desain Plot Split, sebagai petak utama abu boiler terdiri dua tingkat abu boiler asal PKS dan pulp), dan subplot adalah dosis abu boiler (0, 3, 6, dan 9 ton/ha). Parameter yang diukur adalah tinggi tanaman, jumlah umbi, berat umbi per rumpun, dan hasil umbi per $\mathrm{m}^{2}$. Hasil penelitian menunjukkan bahwa tinggi tanaman meningkat secara nyata dalam penerapan 3 ton/ha abu dari dua sumber, jumlah umbi per sampel rumpun meningkat tajam pada penerapan 6 ton/ha abu dari PKS, serta berat umbi per rumpun dan Hasil umbi per $\mathrm{m}^{2}$ cenderung meningkat dengan aplikasi 3-9 ton/ha, peningkatan lebih besar dengan dosis abu yang lebih tinggi dari kedua sumber.

Kata kunci: Abu boiler, Gambut, dan Bawang merah

\section{PENDAHULUAN}

Bawang merah (Allium ascalonicum L.) salah satu komoditi hortikultura yang dibutuhkan sebagai bumbu pada hampir setiap jenis masakan yang tidak dapat digantikan dengan bumbu lain. Bawang merah juga dimanfaatkan dalam industri pangan dan industri farmasi. Bawang merah juga mempunyai efek antiseptik dari senyawa alliin dan allisin. Senyawa Alliin maupun Allisin oleh enzim Allisiin liase diubah menjadi asam piruvat, ammonia dan Allisin antimikroba yang bersifat bakterisida (Mahdiana, 2010).

Badan Pusat Statistik Indonesia (2014) melaporkan bahwa produktivitas bawang merah 4 ton/ha dari total luas panen 3 ha dengan produksi 12 ton pada tahun 2013. Sementara 
potensinya dapat mencapai 10-12 ton/ha (Samsuddin, 2000). Rendahnya produksi dan produktivitas bawang merah perlu ditingkatkan, hal ini dapat dilakukan melalui perluasan area tanam dan pemberian input.Perluasan area tanam dapat dilakukan pada lahan gambut.

Budidaya tanaman hortikultura seperti bawang merah pada lahan gambut memiliki beberapa kendala, antara lain kendala fisik dan kimia. Kendala fisik diantaranya kelebihan air yang dapat diatasi dengan pembuatan saluran drainase. Kendala kimia antara lain ketersediaan unsur hara makro seperti N, P, K, $\mathrm{Ca}, \mathrm{Mg}$, haramikro seperti $\mathrm{Cu}, \mathrm{Zn}, \mathrm{Mn}$, Bo, dan kejenuhan basa serta $\mathrm{pH}$ yang rendah tetapi mempunyai Kapasitas Tukar Kation (KTK) yang tinggi (Simbolon, 2009). Agus et al (2008) juga melaporkan $\mathrm{pH}$ tanah gambut memiliki kisaran 3-5, dan KTK tanah gambut tergolong tinggi, tetapi kejenuhan basa (KB) sangat rendah.Tanah gambut dengan ciri KTK tinggitetapi persentase $\mathrm{KB}$ sangat rendah akan menyulitkan penyerapan hara, terutama basabasa yang diperlukan oleh tanaman. Namun disamping berbagai kendala tersebut tanah gambut memiliki tekstur yang remah sehingga mendukung untuk budidaya bawang merah.

Kendala fisik dan kimia pada lahan gambutdapat diatasi dengan pemberian bahan pembenah tanah atau amelioran. Amelioran yang digunakan berupa abu boiler asal pabrik PKS dan pulp.Kandungan hara yang terdapat di dalam abu boiler asal PKS terdiri dari $\mathrm{SiO}_{2} 58,02 \%, \mathrm{Al}_{2} \mathrm{O}_{3} 8,7 \%, \mathrm{Fe}_{2} \mathrm{O}_{3} 2,6 \%, \mathrm{CaO}$, $\mathrm{MgO}, \mathrm{Na}_{2} \mathrm{O} 0,41 \%, \mathrm{~K}_{2} \mathrm{O}$, dan $\mathrm{H}_{2} \mathrm{O} 1,97 \%$ Hutahean (2007).Wahid (2009) juga melaporkan bahwa abu boiler asal pabrik PKS mengandungP 2,67\%, K 3,89\%, Mg 1,89\%, Ca $38,06 \%$, dan mengandung senyawa basa-basa yang tinggi.

Kandungan hara didalam abu boiler asal

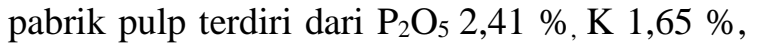
$\mathrm{Ca} 4,30 \%, \mathrm{Mg} 3,91 \%$, Fe 1,25\%, Al 2,96\%, $\mathrm{Zn} \quad 32,30 \quad \mathrm{mg} / \mathrm{kg}$, dan $\mathrm{Cu} \quad 17,5 \quad \mathrm{mg} / \mathrm{kg}$ (Lumbantobing, 2012). Rini et al, (2005) menambahkan bahwa $\mathrm{pH}$ abu boiler asal pabrik pulp berkisar antara 10-13. Berdasarkan komposisi unsur hara dari kedua sumber abu boiler tergolong lengkap serta bersifat basa sehingga dapat meningkatkan $\mathrm{pH}$ tanah diharapkan mampu mengatasi permasalah pada tanah gambut. Tujuan penelitian untuk mempelajari pengaruh pemberian abu boiler asal pabrik pengolahan kelapa sawit (PKS) dan pulp terhadap pertumbuhan dan hasil bawang merah (Allium ascalonicum L.) pada lahan gambut.

\section{BAHAN DAN METODE}

Penelitian dilaksanakan di kebun percobaan Fakultas Pertanian, Desa Rimbo Panjang, Kabupaten Kampar, Provinsi Riaudari bulan Agustus sampai November 2015.

Bahan yang digunakan adalah umbi bawang merah varietas bima, abu boiler asal pabrik PKS dan pulp, pupuk urea, SP-36, KCl dan pestisida (Dithane M-45). Alat-alat yang digunakan adalah alat untuk pengolahan tanah, alat tulis.

Penelitian menggunakan rancangan petak terbagi (Split Plot Design), sebagai petak utama adalah abu boiler terdiri dari dua taraf (abu boiler asal pabrik PKS dan pulp), dan anak petak adalah dosis abu boiler $(0,3,6$, dan 9 ton/ha), 8 kombinasi masing-masing diulang 3 kali. Data hasil pengamatan dianalisis secara statistik menggunakansidik ragam, danuji lanjut beda nyata terkecil (BNT) pada taraf $5 \%$.

\section{HASIL DAN PEMBAHASAN}

\section{Tinggi Tanaman}

Tabel 1 menunjukkan bahwa tinggi tanaman meningkat secara nyata dengan pemberian 3 ton/ha abu dari kedua sumber dibandingkan tanpa abu, peningkatan dosis abu pabrik PKS 9 ton/ha dan pulp 6 ton/ha masih meningkatkan tinggi tanaman secara nyata dibandingkan dosis 3 ton/ha.

Unsur Fosfor yang terdapat didalam abu boiler asal pabrik PKS dan pulp berperan dalam proses fotosintesis, respirasi dan metabolisme tanaman sehingga mendorong laju pertumbuhan tanaman. Kalium berperan sebagai aktivator dari berbagai enzim yang esensial dalam reaksi fotosintesis dan respirasi serta untuk enzim yang terlibat dalam sintesis protein dan pati (Lakitan, 1995). Selain unsur hara $\mathrm{P}$ dan K, Ca juga berperan penting dalam proses pembelahan sel sehingga turut membantu meningkatkan komponen pertumbuhan tinggi tanaman, jumlah daun, kecepatan membentuk umbi dan hasil tanaman bawang merah. Hal ini sesuai dengan pendapat Hilman (1994) yang menyatakan 
bahwa penambahan unsur $\mathrm{K}, \mathrm{P}$, dan $\mathrm{Mg}$ dapat meningkatkan pertumbuhan vegetatif tanaman bawang merah.

Sebagian besar unsur hara yang dibutuhkan tanaman diserap dari larutan tanah melalui akar, ketersedian hara yang optimal pada larutan tanah akan berpengaruh terhadap pola penyebaran akar dan juga pembentukan bulu-bulu akar.
Banyaknya bulu-bulu akar akan mengakibatkan peningkatan kontak langsung antara permukaan akar dengan air dan unsur hara serta memudahkan proses penyerapan air dan hara. bakar dari kedua sumber abu boiler juga berbeda.

Tabel 1. Tinggi tanaman bawang merah umur 42 HST $(\mathrm{cm})$ pada lahan gambut yang di aplikasikan abu boiler dari dua sumber

\begin{tabular}{ccc}
\hline Sumber Abu Boiler & Dosis (ton/ha) & Tinggi tanaman $(\mathrm{cm})$ \\
\hline \multirow{3}{*}{ Pabrik PKS } & 0 & $11,310 \mathrm{c}$ \\
& 3 & $22,053 \mathrm{~b}$ \\
Pabrik Pulp & 6 & $22,253 \mathrm{~b}$ \\
& 9 & $26,520 \mathrm{a}$ \\
\hline \multirow{2}{*}{ Pan } & 6 & $21,020 \mathrm{~b}$ \\
& 9 & $26,413 \mathrm{a}$ \\
\hline
\end{tabular}

Angka-angka yang diikuti oleh huruf kecil yang sama menunjukkan berbeda tidak nyata menurut uji lanjut BNT pada taraf $5 \%$. HST $=$ Hari Setelah Tanam.

Perlakuan abu boiler asal Pabrik PKS membutuhkan dosis yang lebih tinggi ( 9 ton/ha) dibandingkan abu boiler asal pabrik pulp (6 ton/ha) dalam meningkatkan tinggi tanaman, ini terjadi karena kadar hara yang terdapat dari kedua abu tersebut berbeda, yang disebabkan oleh bahan bakar dari kedua sumber abu juga berbeda.

\section{Jumlah Umbi Per Rumpun}

Tabel 2 menunjukkan bahwa jumlah umbi per rumpun meningkat secara nyata dengan pemberian abu boiler asal pabrik PKS dosis 6 ton/ha dan cenderung meningkat dengan perlakuan abu boiler asal pabrik pulp dosis 3 ton/ha dibandingkan tanpa abu, peningkatan dosis selanjutnya tidak memberikan pengaruh yang nyata.

Tabel 2. Jumlah umbi per rumpun pada lahan gambut yang di aplikasikan abu boiler dari dua sumber

\begin{tabular}{ccc}
\hline Sumber Abu Boiler & Dosis(ton/ha) & Jumlah umbi per rumpun (umbi/rumpun) \\
\hline \multirow{3}{*}{ Pabrik PKS } & 0 & $6,700 \mathrm{~b}$ \\
& 3 & $8,933 \mathrm{ab}$ \\
Pabrik Pulp & 6 & $10,267 \mathrm{a}$ \\
& 9 & $9,667 \mathrm{a}$ \\
\hline \multirow{2}{*}{ Pan } & 3 & $8,200 \mathrm{ab}$ \\
& 6 & $9,000 \mathrm{ab}$ \\
\hline
\end{tabular}

Angka-angka yang diikuti oleh huruf kecil yang sama menunjukkan berbeda tidak nyata menurut uji lanjut BNT pada taraf $5 \%$.

Seperti yang telah diterangkan sebelumnya, peningkatan jumlah umbi per rumpun sampel disebabkan karena dengan meningkatnya dosis abu yang diberikan dapat berkontribusi dalam peningkatan ketersedian hara didalam tanah secara lengkap.Pemberian abu boiler asal pabrik PKS dosis 6 ton/ha memberikan hasil terbaik dibandingkan abu boiler asal pulp, ini terjadi karena kandungan dan kadar hara didalam masing-masing abu boiler berbeda yang disebabkan oleh bahan Perbedaan kadar hara akan mengakibatkan kontribusi hara dalam meningkatkan ketersedian hara didalam tanah juga berbeda yang bisa diserap oleh akartanaman, sehingga mempengaruhi prosesfisiologis dan metabolisme tanaman. Semakin meningkat ketersediaan hara didalam larutan tanah yang bisa diserap oleh akar 
tanaman akan menyebabkan akar tanaman semakin menyebar dan juga membentuk bulubulu akar yang lebih banyak sehingga membantu proses penyerapan hara. Banyaknya akar tanaman menyerap hara akan berpengaruh pada pertumbuhan dan produksi tanaman.

Pembentukan umbi secara umum sangat dipengaruhi oleh unsur $\mathrm{K}$. Unsur K didalam abu boiler asalpabrik PKS sebanyak 3,89\% (Wahid, 2009), lebih tinggi dibandingkan unsur $\mathrm{K}$ yang terdapat didalam abu boiler asal pulp $1,65 \%$ (Lumbantobing, 2012). Hal ini sejalan dengan pendapat Napitupulu dan Winarto (2009) yang mengatakan bahwa kalium berperan dalam meningkatkan pertumbuhan vegetatif tanaman seperti pembentukan, pembesaran umbi dan berpengaruh dalam meningkatkan bobot bawang merah. Selain hara $\mathrm{K}$ yang terdapat didalam abu boiler asal pabrik PKS juga terdapat unsur $\mathrm{Ca}$ yang turut membantu meningkatkan komponen tinggi tanaman, jumlah daun, kecepatan membentuk umbi dan hasil tanaman bawang merah.

Seperti yang telah diterangkan sebelumnya, peningkatan jumlah umbi per rumpun sampel disebabkan karena dengan meningkatnya dosis abu yang diberikan dapat berkontribusi dalam peningkatan ketersedian hara didalam tanah secara lengkap.Pemberian abu boiler asal pabrik PKS dosis 6 ton/ha memberikan hasil terbaik dibandingkan abu boiler asal pulp, ini terjadi karena kandungan dan kadar hara didalam masing-masing abu boiler berbeda yang disebabkan oleh bahan bakar dari kedua sumber abu boiler juga berbeda.

Perbedaan kadar hara akan mengakibatkan kontribusi hara dalam meningkatkan ketersedian hara didalam tanah juga berbeda yang bisa diserap oleh akartanaman, sehingga mempengaruhi prosesfisiologis dan metabolisme tanaman. Semakin meningkat ketersediaan hara didalam larutan tanah yang bisa diserap oleh akar tanaman akan menyebabkan akar tanaman semakin menyebar dan juga membentuk bulubulu akar yang lebih banyak sehingga membantu proses penyerapan hara. Banyaknya akar tanaman menyerap hara akan berpengaruh pada pertumbuhan dan produksi tanaman.

Pembentukan umbi secara umum sangat dipengaruhi oleh unsur $\mathrm{K}$. Unsur $\mathrm{K}$ didalam abu boiler asalpabrik PKS sebanyak
$3,89 \%$ (Wahid, 2009), lebih tinggi dibandingkan unsur $\mathrm{K}$ yang terdapat didalam abu boiler asal pulp 1,65 \% (Lumbantobing, 2012). Hal ini sejalan dengan pendapat Napitupulu dan Winarto (2009) yang mengatakan bahwa kalium berperan dalam meningkatkan pertumbuhan vegetatif tanaman seperti pembentukan, pembesaran umbi dan berpengaruh dalam meningkatkan bobot bawang merah. Selain hara K yang terdapat didalam abu boiler asal pabrik PKS juga terdapat unsur $\mathrm{Ca}$ yang turut membantu meningkatkan komponen tinggi tanaman, jumlah daun, kecepatan membentuk umbi dan hasil tanaman bawang merah.

Jumlah umbi per rumpun sampel yang diberi abu boiler asal pabrik pulp tidak memberikan hasil yang nyata, diduga karena kadar hara yang terkandung pada abu boiler asal pabrik pulplebih rendah dibandingkan dengan abu boiler asal pabrik PKS, selain itu juga disebabkan oleh sifat tanah gambut yang kesuburannya rendah. Rendahnya kadar hara dari abu boiler asal pabrik pulpakan mempengaruhi pembentukan cakram hingga terbentuknya umbi. Unsur hara yang dibutuhkan dalam penyusunan jaringan adalah $\mathrm{P}$ dan $\mathrm{K}$ yang berperan dalam mengaktifkan enzim-enzim pertumbuhan. Unsur P dan K pada abu boiler asal pabrik pulplebih rendah dari abu boiler asal PKS. Hal ini didukung oleh pendapat Salisburry dan Ross (1995) yang mengatakan pertumbuhan tanaman akan optimal jika unsur hara yang dibutuhkan tersedia dalam jumlah dan bentuk yang sesuai dengan kebutuhan tanaman.

\section{Berat Umbi Per Rumpun}

Tabel 3 menunjukkan bahwa berat umbi per rumpun cenderung meningkat dengan pemberian dosis 3-9 ton/ha abu boiler asal pabrik PKS dan pulp dibandingkan tanpa abu.

Hal ini disebabkan karena tanah gambut yang digunakan memiliki kesuburan yang rendah. Tanah gambut dengan kandungan $\mathrm{Ca}-$ dd, K-dd, Na-dd, dan Fosfor yang rendahdisebabkan oleh senyawa asam organik sangat tinggi dan tinggi kapasitas tukar kation (KTK) (Arman, 2016). Tanahgambut dengan ciri KTK sangat tinggi, tetapi persentase KB sangat rendah akan menyulitkan penyerapan hara terutama basa-basa yang diperlukan oleh 
Pengaruh Pemberian Abu Boiler terhadap Pertumbuhan dan Hasil Bawang Merah (Allium ascalonicum L.) di Lahan Gambut.

tanaman. Rendahnya kadar hara mengakibatkan perkembangan akar menjadi tidak optimal, sehingga akar sulit dalam menyerap unsur hara yang terdapat pada larutan tanah dan akan mempengaruhi proses pembentukan umbi.

Tabel 3. Berat umbi per rumpun pada lahan gambut yang di aplikasikan abu boiler dari dua sumber

\begin{tabular}{ccc}
\hline Sumber Abu Boiler & Dosis(ton/ha) & Berat umbi per rumpun (g/rumpun) \\
\hline \multirow{3}{*}{ Pabrik PKS } & 0 & $7,640 \mathrm{a}$ \\
& 3 & $6,700 \mathrm{a}$ \\
& 6 & $9,333 \mathrm{a}$ \\
Pabrik Pulp & 9 & $11,067 \mathrm{a}$ \\
\hline & 3 & $8,213 \mathrm{a}$ \\
& 6 & $8,800 \mathrm{a}$ \\
\hline
\end{tabular}

Angka-angka yang diikuti oleh huruf kecil yang sama menunjukkan berbeda tidak nyata menurut uji lanjut BNT pada taraf $5 \%$.

Pembentukan umbi sangat dipengaruhi oleh unsur K, unsur K yang terdapat pada kedua sumber abu sulit diserap oleh tanaman sehingga mengakibatkan proses fisiologis didalam jaringan tanaman terhambat. Peningkatan dosis abu boiler yang lebih tinggi cenderung masih dapat meningkatkan berat umbi dan akan memberikan kontribusi yang lebih banyak dalam meningkatkan ketersediaan hara pada tanah gambut. Kalium berperan dalam meningkatkan pertumbuhan vegetatif tanaman seperti pembentukan, pembesarandan berpengaruh dalam meningkatkan bobot bawang merah (Napitupulu dan Winarto, 2009). Hal ini sejalan dengan pendapat Damanik et al. (2010) bahwa kalium sangat dibutuhkan untuk proses fotosintesis serta dapat meningkatkan berat umbi. Indriani (1998) juga menambahkan bahwa kalium penting bagi pertumbuhan tanaman antara lain untuk mempertinggi tanaman dan memperbaiki produksi umbi.

\section{Hasil Umbi Per $\mathbf{m}^{2}$}

Tabel 4 menunjukkan bahwa hasil umbi per $\mathrm{m}^{2}$ cenderung meningkat dengan pemberian dosis 3-9 ton/ha abu boiler asal pabrik PKS dan pulp dibandingkan tanpa abu. Hasil penelitian didapatkan hasil perm ${ }^{2}$ tertinggi pada perlakuan abu boiler asal pabrik pulp dosis 9ton/ha yaitu 239,36 g, jika dikonversikan per hektar maka setara dengan 2,39 ton/ha dan hasil ini jauh lebih rendah bila dilihat dari potensi produktivitas bawang merah yang bisa mencapai 10-12 ton/ha.

Tabel 4. Hasilumbi per $\mathrm{m}^{2}$ pada lahan gambut yang di aplikasikan abu boiler dari dua sumber

\begin{tabular}{ccc}
\hline Sumber Abu Boiler & Dosis (ton/ha) & Hasil umbi per $\mathrm{m}^{2}\left(\mathrm{~g} / \mathrm{m}^{2}\right)$ \\
\hline \multirow{3}{*}{ Pabrik PKS } & 0 & $119,88 \mathrm{a}$ \\
& 3 & $139,24 \mathrm{a}$ \\
& 6 & $185,90 \mathrm{a}$ \\
Pabrik Pulp & 9 & $200,97 \mathrm{a}$ \\
& 3 & $179,29 \mathrm{a}$ \\
& 9 & $217,23 \mathrm{a}$ \\
\hline
\end{tabular}

Angka-angka yang diikuti oleh huruf kecil yang sama menunjukkan berbeda tidak nyata menurut uji lanjut BNT pada taraf $5 \%$.

Rendahnya hasil bawang merah ini karena pemberian abu boiler asal pabrik PKS dan pulp sampai dosis 9 ton/ha belum mampu menyediakan hara yang dibutuhkan oleh tanaman di tanah gambut secara optimal dan perlakuan dosis sampai 9 ton/ha secara umum tidak memberikan hasil yang nyata pada produksi tanaman dilahan gambut. Hal ini dapat dilihat pada parameter jumlah umbi per 
rumpun, berat umbi per rumpun dan produksi umbi per $\mathrm{m}^{2}$.

Pembentukan umbi dipengaruhi oleh hara $\mathrm{K}$, hara $\mathrm{K}$ potensial pada tanah gambut tergolong sangat tinggi, namun tingginya hara $\mathrm{K}$ potensial tidak bisa meningkatkan produksi umbi per $\mathrm{m}^{2}$.Hal ini disebabkankarena sifat tanah gambut dengan KTK sangat tinggi, tetapi persentase $\mathrm{KB}$ sangat rendah akan menyulitkan penyerapan hara diantaranya $\mathrm{K}$ bagi tanaman. Selain kalium, unsur nitrogen juga mempengaruhi hasil umbi.Unsur nitrogen sangatpenting bagi tanaman sebagai penyusun asam amino,amida, nukleotida serta esensial untuk pembelahan danpembesaran sel. Penambahan abu boiler dari kedua sumber tidak dapat menyumbangkan hara nitrogen, karena kandungan abu boiler tidak terdapat hara nitrogen.

Menurut Napitupulu dan Winarto (2010) bila unsur $\mathrm{K}$ dalam keadaan cukup dapat memberikan pertumbuhan bawang merah lebih optimal dan menunjukkan hasil yang baik. Salisbury dan Ross (1995) menjelaskan bahwa unsur hara yang diserap oleh tanaman dimanfaatkan dalam proses fotosintesis, hal ini sejalan dengan pendapat Winarso (2005) jika unsur hara dalam keadaan cukup maka biosintesis dapat berjalan lancar, sehingga karbohidrat yang dihasilkan akan semakin banyak dan dapat disimpan sebagai cadangan makanan, dengan demikian timbunan karbohidrat ini akan mengakibatkan terjadinya peningkatan berat basah tanaman.

\section{KESIMPULAN}

Dari hasil penelitian dapat disimpulkan bahwa tinggi tanaman meningkat pada aplikasi 3 ton/ha abu dari dua sumber, jumlah umbi per rumpun sampel meningkat pada aplikasi 6 ton/ha abu asal PKS, serta berat umbi per rumpun dan hasil umbi per $\mathrm{m}^{2}$ cenderung meningkat pada aplikasi 3-9 ton/ha abu dari kedua sumber.

\section{DAFTAR PUSTAKA}

Agus, F. dan Subiksa, IGM. 2008. Lahan Gambut : Potensi untuk Pertanian dan Aspek Lingkungan. Balai Penelitian Tanah dan Word Agroforestry Center (ICRAF). Bogor, Indonesia.
Arman, Z. 2016. Respons Fisiologi, Pertumbuhan, Produksi dan Serapan P Bawang Merah (Allium ascalonicum L.) terhadap Pemberian Trichokompos Tandan Kosong Kelapa Sawit Terformulasi dan Pupuk P di Lahan Gambut. Tesis Pascasarjana Universitas Riau. Pekanbaru.

Badan Pusat Statistik Indonesia. 2014. Luas Panen, Produksi dan Produktivitas Bawang Merah, 2009-2013. http//www.bps.go.id. diakses tanggal 30 Januari 2015.

Damanik, M. M.B., B.E. Hasibuan, Fauzi, Sarifuddin, H. Hanum., 2010. Kesuburan Tanah dan Pemupukan.USUPress. Medan

Hilman, Y. 1994. Pengaruh Cara Aplikasi Fosfat dan Kombinasi Pupuk Nitrogen, Fosfat dan Kalium Terhadap Pertumbuhan dan Hasil Bawang Merah ditanam dengan Sistem Complongan. Bul. Penel. Hort : 26 (3) : 1-10

Hutahean, H. 2007. Sifat Mekanik Beton Yang Dicampur Dengan Abu Cangkang Sawit. Skripsi Jurusan Fisika. FMIPA UNIMED. Medan.

Lakitan, B. 1995. Hortikultura I. Teori Budidaya dan Pasca Panen. Raja Grafindo Persada. Jakarta. $219 \mathrm{hlm}$.

Lumbantobing, R. M. 2012. Penggunaan Amelioran Dan Pupuk Fosfor Untuk Memperbaiki Sifat-Sifat Kimia Gambut dan Pertumbuhan Acacia crassicarpa. Tesis Program Pasca Sarjana. Universitas Riau, Pekanbaru.

Mahdiana, R. 2010. Mengenal, Mencegah, dan Mengobati Penularan Penyakit dan Infeksi. Citra Pustaka. Yogyakarta.

NapitupuluD danL. Winarto. 2010. Pengaruh Pemberian Pupuk N Dan K Terhadap Pertumbuhan Dan Produksi Bawang Merah. J.Hort.20(1):27-35.

Rini, Hazli, N., Hamzar, S., Teguh, B.P. 2005. Pemberian Fly Ash Pada Lahan Gambut Untuk Mereduksi Asam Humat dan Kaitannya Terhadap Kalsium (Ca) Dan Magnesium (Mg). MIPA FKIP Universitas Riau. Pekanbaru.

Salisbury, Frank B dan Cleon W Ross. 1995. Fisiologi Tumbuhan Jilid 1. Bandung: ITB. 
Pengaruh Pemberian Abu Boiler terhadap Pertumbuhan dan Hasil Bawang Merah (Allium ascalonicum L.) di Lahan Gambut.

Samsuddin. 2000. Bawang Merah.

Bima Cipta, Bandung. 14 hlm.

Winarso.2005. Petunjuk pemberian Pemupukan

dalam mengembangkan budidaya

tanaman mentimun. Rineka Cipta.

Jakarta. 